\title{
Book Review: 'Neurogastronomy: how the brain creates flavor and why it matters' by Gordon M. Shepherd
}

\author{
Charles Spence
}

'Neurogastronomy', the title of Gordon Shepherd's new book (Shepherd, [1]), refers to the study of the complex brain processes that give rise to the flavours that we all experience when eating or drinking. This term, which Shepherd apparently first coined back in 2006 in an article in Nature Insight (Shepherd, [2], p. 320), can be contextualized in terms of the 'neuromania' that has been sweeping through the cognitive neurosciences over the last few years. However, as Legrenzi and Umiltà [3] make abundantly clear in their critical (albeit pocketsized) appraisal of the new 'neuro-' sciences, one should not necessarily believe that just because a research field has been christened by the pleonastic use of the 'neuro' prefix (see Legrenzi and Umiltà, [3], p. 9), that it necessarily means that we understand the underlying science, nor that what follows is necessarily all that new! As Raymond Tallis, emeritus professor of geriatric medicine at the University of Manchester noted, in a piece attacking A. S. Byatt's neuroaesthetic reading of the poetry of John Donne, there is a lot of 'Neuromythology' about (Tallis, [4]; see also 'The trouble with neuroaesthetics', http://www.guardian.co.uk/books/booksblog/2008/jun/04/ thetroublewithneuroaestheti, downloaded on 15 August 2012). You have been warned.

Gordon Shepherd, a distinguished professor at Yale School of Medicine whose research, focuses primarily on the neurobiology of the olfactory system in the animal model, has appeared frequently in many of the top science journals, including Scientific American, and Nature. Indeed, his experimental work has, for many years, been at the cutting edge in terms of furthering our understanding of the sense of smell. It is safe to say, then, that Shepherd probably knows more about olfaction than virtually anyone else. Unfortunately, though, Shepherd spends the first 12 chapters (or 40\%) of his new book

* Correspondence: charles.spence@psy.ox.ac.uk

Crossmodal Research Laboratory, Oxford University, South Parks Road, Oxford OX1 3UD, UK \\ C Biomed Central}

discussing the intricacies, and the current understanding, of the neurobiology of olfaction in humans and other species. Hence, while the reader gets to learn a great deal about the inner workings of the nose, and, more importantly, how the brain manages to decode the complex patterns of information (which Shepherd likens to a Pointillist painting) it receives from the olfactory epithelium, the relevance of much of this material to the field of contemporary gastronomy is often less than clear.

Had this volume been called 'Neuro-olfaction' then this bias (in the material covered) would have been perfectly understandable. Furthermore, it may well be true that as many a popular science writer will tell you (and contrary to folk intuition, [5]), that as much as $80 \%$ of what we think of as the flavour of food and drink actually comes from information provided by the nose (for example, $[6,7])$. As Shepherd puts it in one section header 'Flavor is mostly retronasal smell' ([1], p. 29). I think that highlights the crux of what is wrong with Shepherd's approach to neurogastronomy. To me, and many of my colleagues, the (neuro-)scientific study of gastronomy is about so much more than merely retronasal olfaction, important though it undoubtedly is to the perception of flavour (see [8]; Spence, $[9,10]$ ).

I would argue that the overrepresentation of olfactory research in Neurogastronomy, while obviously playing to Shepherd's strengths as an outstanding neuroscientist, comes at the cost of a neglect of the other senses, and the crucial role that they are now known to play in the multisensory perception of flavour. What is more, Shepherd's prose falls uncomfortably between the dry academic writing that one would expect to find in a peer-reviewed journal article, and the familiarity that one might expect to find in a mass-market popular trade volume. It is hard to know, for example, what an up-and-coming chef interested in learning more about the brain and how the latest neuroscience insights could be used to enhance the dishes that they deliver to the table would make of the following

(c) 2012 Spence; licensee BioMed Central Ltd. This is an Open Access article distributed under the terms of the Creative Commons Attribution License (http://creativecommons.org/licenses/by/2.0), which permits unrestricted use, distribution, and reproduction in any medium, provided the original work is properly cited. 
sentence: 'It was already known that cyclic AMP occurs in a signaling pathway that starts with a receptor that gives a microkick to a so-called $G$ protein, which forms a large class of G protein-coupled receptors (GPCRs)' ([1], p. 51).

Now, it could certainly be said that a book on flavour perception need go no further than the senses of taste (or gustation), smell, and possibly also the trigeminal sense (for example, [11]). Indeed, according to the International Standards Organization [12,13], flavour is defined as a: 'Complex combination of the olfactory, gustatory and trigeminal sensations perceived during tasting. The flavour may be influenced by tactile, thermal, painful and/or kinaesthetic effects'. Thus, an argument could be made that auditory and visual cues, while possibly modulating flavour perception, are not constitutive of it, and hence need not enter into a book on gastronomy, let alone neurogastronomy. That said, if you are going to include chapters on vision and audition and their role in flavour perception (Chapters 16 and 17, respectively), then one would at least hope for something of an up-to-date coverage of the relevant material (to match what we find in the earlier chapters on the sense of smell). Alas, that is not what we get. The problem is that Shepherd devotes just 12 pages (less that $5 \%$ of the book) to covering both of these senses, and their role in our gastronomic experiences. What is more, the material covered in these chapters is both limited, and, in part, simply outdated.

Take, for example, the chapter on hearing and flavour, a topic that I myself am particularly interested in. The most recent reference in this chapter is a decade old. As such, Shepherd simply fails to cover any of the exciting recent work that has demonstrated just how much of an influence what we hear actually has on what we taste (see [14], in press, for a recent review of this rapidly growing field). There are a number of studies out there now that have demonstrated how the freshness and crispness of dry food products, such as potato chips (or crisps), biscuits, and pretzels can be dramatically changed simply by changing the self-generated sounds that a person hears when they bite into such a foodstuff (for example, [15]).

Findings such as these, for which Max Zampini and I were awarded the IG Nobel prize for Nutrition back in 2008, have now stimulated some of the world's foremost molecular gastronomy chefs, such as Heston Blumenthal (whose most famous restaurant is the three-Michelinstarred The Fat Duck restaurant; see http://www.thefatduck. co.uk/) to include a sonic element in some of the gastronomic experiences that they deliver to their customers. Take 'The sound of the sea' seafood dish, which has been the signature dish on the tasting menu at Blumenthal's flagship Bray restaurant for a number of years now. The dish, which looks like the seaside, with sand, foam, seaweed and, if you're lucky, some seafood, comes to the table together with a conch shell out of which emerge a pair of iPod headphones. If you are fortunate enough to try this dish, the waiter will politely suggest that you put the headphones on before you taste the food, whereupon you will hear the sounds of the seaside (the English seaside that is; think waves crashing on the beach, and a few seagulls swirling around overhead).

This dish emerged from research conducted here in Oxford (where, coincidentally, Shepherd started his research career) demonstrating that oysters are rated as tasting better (that is, more pleasant) when you hear such a soundtrack than when you hear the sound of farmyard chickens, clinking cutlery, or even the modern jazz that seems to be favoured as the sonic background by a few too many of our top restaurants [16]. In fact, the last couple of years or so has seen the publication of a number of intriguing studies, suggesting that background music, and soundscapes, can have a much more profound effect on many of our multisensory taste and flavour experiences than any of us would, I suspect, ever have imagined (for example, see [17-19]). This, to me, is much more what neurogastronomy is really all about.

Visual cues also exert a profound influence both on the flavour of the food we eat, and the intensity of the tastes (see [20], for a review of some of the more than 200 studies that have been published in the area since the first report back in [21] by Moir). 'Eye appeal is half the meal' as is sometimes said. While visual cues may not be constitutive of many people's definition of flavour, it is critical to realize that chefs very often play with their diner's sensory expectations with the use of colour and texture. Changing what something looks like is undoubtedly one of the most frequently used means of creating surprise in a dish (see Spence, [9]). Betina Piqueras-Fiszman and I have argued elsewhere that such visually mediated sensory incongruence is a key component in much of contemporary molecular gastronomic practice [22], as such it seems strange not to read anything about the neuroscience of surprise in Shepherd's volume. Admittedly, Shepherd covers a few of the bestknown findings in this area ([23,24]; Morrot, Brochet, and Dubourdieu, [25]). But note, once again, that the emphasis here is squarely on colour's influence on odour perception, both orthonasal and retronasal (as highlighted by the discussion of the studies published by $[23,24])$.

Things certainly seem to be looking up when, in the section entitled 'Wine color and flavor', Shepherd starts by stating 'Dramatic examples of the effect of color on flavor have come from...' ([1], p. 139). He then proceeds to describe Morrot et al.'s [25] rightly famous finding that students on an university oenology course could be fooled into thinking that a white wine was similar to a 
red wine simply by adding a few drops of odourless red food dye. But note that this study is not about flavour at all (although the writing in Morrot et al.'s original article is admittedly confusing in places). The participants in the critical part of the experiment (when the food dye was added) were only allowed to sniff the wines, not taste them. Hence, the most that can be said with any certainty is that this study provides yet another demonstration of the profound influence that visual cues have on olfactory (in this case, orthonasal) perception (see [26], for a review of studies on wine colour).

Perhaps this apparent error in describing Morrot et al.'s [25] study can simply be put down to the uncertainty that exists given the various different definitions of what, exactly, flavours are thought to be. It is certainly true that a number of those working in the food/ flavour industry happily refer to the orthonasal aroma of a food or beverage item in terms of its flavour (given that is where so much of the information resides). However, on the other hand, many others fervently believe that flavours require the stimulation of both the olfactory and gustatory systems. That, certainly, seems to be Shepherd's position when he writes on p. 16 that 'Brillat-Savarin thus identified clearly the important role of smell in taste, but unfortunately didn't differentiate clearly between taste as a single sense and "taste" as a combined sense of smell and taste. That is why we will call the combined sense "flavor"'. ${ }^{a}$ Now while the question of what attributes of a food or beverage can be justifiably referred to as flavour attributes, and the question of whether flavours reside 'out there' or 'in us' (see [27]), are devilishly tricky, I would hazard a guess that philosophy may have more chance of helping us to answer these questions that the latest developments, or findings, emerging from contemporary neuroscience (or neurogastronomy).

It turns out that people, and this includes many scientists who certainly ought to know better, are more likely to accept an argument (regardless of its veracity), if it happens to be accompanied by a colourful brain image ([28]; see also [29]). The more colourful the brain image, the more gullible we appear to be. Such findings have led some to suggest (with their tongue presumably firmly in their cheek) that brain images really ought to be presented in the press with a cautionary note to the reader. Reading Shepherd's new book made me think that perhaps the same should be done on the back cover of those volumes whose titles start with the 'neuro-' prefix, be it neurogastronomy [1], neuroaesthetics [30,31], neuroculture [32], neuroethology, neurodesign, or neuromarketing [33].

Neurogastronomy, then, is certainly not the 'paradigmshifting trip' through the 'human brain flavor system' that we are promised on the cover. Shepherd fails to provide an accessible and up-to-date guide to the emerging neuroscience of multisensory flavour perception. There can be no doubting that this volume does provide an accessible (accessible, that is, if you happen to be a scientist with an interest in neurobiology) review of our rapidly growing understanding of the neuroscience of olfaction. But Shepherd's failure to touch on (m)any of the exciting recent interactions that have been taking place between molecular gastronomy chefs and neuroscientists, as captured in volumes such as Heston Blumenthal's The Fat Duck Cookbook [8], means that he fails to deliver fully on the second part of the book's subtitle, namely 'why it matters'.

Shepherd ends with a quote from Shakespeare's 'As you like it'. I must, however, admit that I was reminded more of another of the great bard's oft-cited gems 'A rose by any other name would smell as sweet' (from Romeo and Juliet). Interesting and authoritative as it undoubtedly is in parts I, for one, am doubtful that Neurogastronomy would have sold as well, or created anything like as much press interest, had it been published under any other name.

\section{Endnote}

${ }^{a}$ Elsewhere in the book, Shepherd states that: 'A common misconception is that the foods contain the flavors. Foods do contain the flavor molecules, but the flavors of those molecules are actually created by our brains' ([1], p. ix, emphasis in the original). Later, he continues 'It is important to realize that flavor doesn't reside in a flavorful food any more than color resides in a colorful object' ([1], p. 5).

\section{Competing interests}

The authors declare that they have no competing interests.

Received: 17 August 2012 Accepted: 21 August 2012

Published: 1 November 2012

\section{References}

1. Shepherd GM: Neurogastronomy: how the brain creates flavor and why it matters. New York: Columbia University Press; 2012.

2. Shepherd GM: Smell images and the flavour system in the human brain. Nature 2006, 444:316-321.

3. Legrenzi P, Umilta C: Neuromania: on the limits of brain science (translated by F. Anderson). Oxford: Oxford University Press; 2011.

4. Tallis R: The neuroscience delusion. In The Times Literary Supplement. 2008. Downloaded from http://tomraworth.com/talls.pdf 17/08/12.

5. Nudds M: The significance of the senses. Proc Aristot Soc 2004, 104:31-51.

6. Martin GN: A neuroanatomy of flavour. Petits Propos Culinaires 2004, 76:58-82.

7. Rosenblum LD: See what I am saying: the extraordinary powers of our five senses. New York: W. W. Norton \& Company Inc.; 2010.

8. Blumenthal H: The big Fat Duck cookbook. London: Bloomsbury; 2008.

9. Spence C: The multisensory perception of flavour. The Psychologist 2010, 23:720-723.

10. Spence C: Multi-sensory integration and the psychophysics of flavour perception. In Food oral processing - fundamentals of eating and sensory perception. Edited by Chen J, Engelen L. Oxford: Blackwell Publishing; 2012:203-219. 
11. Green BG: Oral chemesthesis: an integral component of flavour. In Flavour perception. Edited by Taylor AJ, Roberts DD. Oxford: Blackwell Publishing; 2004:151-171.

12. ISO: Standard 5492: Terms relating to sensory analysis. International Organization for Standardization; 1992.

13. ISO: Standard 5492: Terms relating to sensory analysis. Internationa Organization for Standardization; 2008.

14. Spence C, Spence C: Auditory contributions to flavour perception and feeding behaviour. Physiol \& Behaviour, in press. http://dx.doi.org/10.1016/j. physbeh.2012.04.022

15. Zampini M, Spence $\mathrm{C}$ : The role of auditory cues in modulating the perceived crispness and staleness of potato chips. J Sens Sci 2004, 19:347-363.

16. Spence C, Shankar MU, Blumenthal H: 'Sound bites': auditory contributions to the perception and consumption of food and drink. In Art and the senses. Edited by Bacci F, Mecher D. Oxford: Oxford University Press; 2011:207-238.

17. Crisinel A-S, Cosser S, King S, Jones R, Petrie J, Spence C: A bittersweet symphony: systematically modulating the taste of food by changing the sonic properties of the soundtrack playing in the background. Food Qual and Preference 2012, 24:201-204.

18. North AC: The effect of background music on the taste of wine. $\mathrm{Br} J$ Psychol 2012, 103:293-301.

19. Spence C: Wine and music. World Fine Wine 2011, 31:96-104.

20. Spence C, Levitan C, Shankar MU, Zampini M: Does food color influence taste and flavor perception in humans? Chemosens Percept 2010, 3:68-84.

21. Moir HC: Some observations on the appreciation of flavour in foodstuffs. J Soc Chem Ind: Chem \& Ind Rev 1936, 14:145-148.

22. Piqueras-Fiszman B, Spence C: Sensory incongruity in the food and beverage sector: art, science, and commercialization. Petits Propos Culinaires 2012, 95:74-118.

23. Engen T: The effect of expectation on judgments of odour. Acta Psychol 1972, 36:450-458.

24. Koza BJ, Cilmi A, Dolese M, Zellner DA: Color enhances orthonasal olfactory intensity and reduces retronasal olfactory intensity. Chem Senses 2005, 30:643-649.

25. Morrot G, Brochet F, Dubourdieu D: The color of odors. Brain Lang 2001, 79:309-320.

26. Spence C: The color of wine - Part 1. The World of Fine Wine 2010, 28:122-129.

27. Auvray $\mathrm{M}$, Spence $\mathrm{C}$ : The multisensory perception of flavor. Conscious Cogn 2008, 17:1016-1031.

28. McCabe D, Castel A: Seeing is believing: the effect of brain images on judgments of scientific reasoning. Cognition 2008, 107:343-352.

29. Weisberg DS, Keil FC, Goodstein J, Rawson E, Gray JR: The seductive allure of neuroscience explanation. J Cogn Neurosci 2008, 20:470-477.

30. Skov M, Vartainian O (Eds): Neuroaesthetics. Amityville: Baywood Publishing Company, Inc: 2009

31. Zeki S: Inner vision: an exploration of art and the brain. Oxford: Oxford University Press; 1999.

32. Rolls ET: Neuroculture: on the implications of brain science. Oxford: Oxford University Press; 2012.

33. Butler MJR: Neuromarketing and the perception of knowledge. J Consum Behav 2008, 7:415-419.

\section{Submit your next manuscript to BioMed Central and take full advantage of:}

- Convenient online submission

- Thorough peer review

- No space constraints or color figure charges

- Immediate publication on acceptance

- Inclusion in PubMed, CAS, Scopus and Google Scholar

- Research which is freely available for redistribution 